\title{
Assessment of quality of life in patients with non-operated pancreatic cancer after videothoracoscopic splanchnicectomy
}

\author{
Jacek Śmigielski, Łukasz Piskorz, Marcin Wawrzycki, Leszek Kutwin, Piotr Misiak, Marian Brocki \\ Department of Thorax, General Surgery and Oncology, Medical University, Lodz, Poland
}

Videosurgery and other miniinvasive techniques 2011; 6 (3): 132-137 DOI: $10.5114 /$ wiitm.2011.24690

\begin{abstract}
Introduction: Pancreatic tumours are a crucial medical issue. The majority of patients report sick in the late stage of carcinoma clinical advancement, which considerably limits the possibility of surgical treatment. Pancreatic cancer patients with no other alternative but palliative treatment constitute a large group.

Aim: To assess pain intensity levels and quality of life of pancreatic cancer patients after videothoracoscopic splanchnicectomy.

Material and methods: Between 2001 January and 2010 November in the Department of Thorax, General Surgery and Oncology of the Medical University of Lodz 262 patients with pancreatic tumours were hospitalized. In 121 cases grade 3 and grade 4 tumours were observed. Hundred and twenty-one videothoracoscopic procedures of sympathetic trunk and ganglion excision were performed in 89 patients.

Results: Before the procedure the pain intensity level according to VAS was 5.66 (3.9-7.2; SD 1.24) in the trial group and 5.46 (4.1-7.1; SD 1.15) in the control group. The quality of life average assessment in both groups did not differ statistically $(p=1.07)$ and was $46.3(32-66 ; S D$ 0.92) in patients before the operation and in the control group 50.3 (41-63; SD 0.75). On the th postoperative day the pain intensity on average was 2.33 (1.2-3.9; SD 0.78) and 4.57 (3.6-5.5; SD 0.69) respectively. One week after the procedure the quality of patients' life was estimated at 64.1 (39-83; SD 1.38) and in the control group at 52.2 (42-65; SD 0.71); the differences are significant $(p<0.05)$. Thirty days after the procedure 12 patients did not take any painkillers (13.5\%), and in the others a considerable decrease of the taken drugs was observed. On average, the pain intensity was estimated at 1.78 (0.6-3.6; SD 0.68). The quality of life, on the other hand, improved considerably in relation to the state prior to the procedure, but increased insignificantly in relation to the state on the $7^{\text {th }}$ postoperative day to 70.9 (52-88; SD 1.14).

Conclusions: Splanchnicectomy is a safe method of cancer pain treatment in patients with advanced pancreatic tumours. Videothoracoscopic excision of visceral nerve thoracic section contributes to the statistically significant decrease of cancer pain intensity and considerably improves the quality of patients' lives.
\end{abstract}

Key words: pancreatic cancer, palliative treatment, videothoracoscopic splanchnicectomy.

\section{Introduction}

Pancreatic tumours are a crucial medical and socio-economic issue. Their diagnostics and treatment constitute a huge problem. There is no single, efficient method of achieving diagnosis and differen- tiation of pancreatic tumours which would offer an opportunity for effective non-invasive or surgical treatment. Nowadays, in the $21^{\text {st }}$ century, despite the diversity of imaging modalities, a surgeon beginning an operation is never certain if a tumour they are going to operate on is malignant or benign. It is often 
found out intraoperatively that a tumour is nonresectable, which means it is too advanced for a radical procedure. The number of such procedures exploratory laparotomies - according to different studies, amounts to $20 \%$ of patients operated on due to pancreatic tumours [1]. Considerable advancement of a tumour and a lack of possibility of establishing a biliary-intestinal anastomosis do not conclude the possibility of further, palliative treatment. Symptoms of pancreatic cancer are scant and produced late. They typically include painless jaundice (up to $82 \%$ ), stomach ache (up to 32\%), weight loss and anorexia (up to 29\%), therapy-resistant pruritus (up to 21\%), vomiting and/or diarrhoea together with progressive malnutrition often indirectly leading to death [2]. However, cancer pain is the most severe and difficult to relieve presentation of a tumour. Videothoracoscopic splanchnicectomy is advisable in patients with tumours which cannot be radically operated on in order to limit cancer pain [3-5]. In 1943 the first excision of visceral nerves was performed using a laparotomic approach, and in 1990 via a thoracotomy approach [6, 7].

Splanchnicectomy consists in excision of the major thoracic visceral nerve made of branches which extend from the $5^{\text {th }}$ to the $10^{\text {th }}$ thoracic sympathetic ganglion. Visceral nerves consist of fibres narrowing the digestive tube, repressing peristaltic motion and increasing the tension of the sphincters. Moreover, they transmit pain stimuli from abdominal viscera [8].

\section{Aim}

To assess pain intensity levels and quality of life of pancreatic cancer patients after palliative videothoracoscopic splanchnicectomy.

\section{Material and methods}

From 2001 January to 2010 November (a 10-year observation period) in total 262 patients with pancreatic tumours were hospitalized in the Department of Thorax, General Surgery and Oncology of the Medical University of Lodz. Apart from interviews and physical examinations, in all patients the following additional diagnostic modalities were used: abdominal ultrasound and/or computed tomography, and/or endoscopic retrograde cholangiopancreatography, and/or magnetic resonance and/or magnetic resonance cholangiopancreatography.
On their basis grade 3 and 4 pancreatic tumours were diagnosed in 121 patients, in whom nonresectability was determined pre- or intraoperatively. In the preoperative period all patients with chronic cancer pain of epigastrium received orally and/or percutaneously painkillers, including narcotic drugs. hundred and twenty-one videothoracoscopic procedures of sympathetic trunk and ganglion removal were performed in 89 patients. The procedure was performed under general anaesthesia with selective intubation one of the main bronchi. The patient was placed in a lateral position, the first visual trocar in the mid-axillary line in the $5^{\text {th }}$ intercostal space, the next two trocars in the $6^{\text {th }}$ and $7^{\text {th }}$ intercostal space in the anterior and posterior axillary line. After the paravertebral incision of the parietal pleura and the preparation of the nerve structures had been performed, the 8-10 cm fragment of innervation was removed. When the splanchnicectomy was over, the lung was ventilated and expanded intraoperatively. Currently drainage is not used. Each time the material was histopathologically examined. In all the patients the pain intensity was assessed before the procedure, on the $7^{\text {th }}$ postoperative day and 30 days after the procedure.

A visual analogue scale (VAS) was used to record subjective estimates of patients' pain intensity [9]. The amount of pain a patient was experiencing was compared to the worst pain imaginable. The first level, "0", meant no pain. Level "1" was a ghost of pain and level "10" meant the maximum pain. SF-36 (Short-Form Health Status Survey) was filled in to assess the quality of life. The protocol consisted of two parts: the first assessed functionality (physical fitness, functioning in society, limitations caused by physical and emotional problems), the second assessed mental fitness, stamina and vitality [10]. The acquired results - the answers were converted according to certain rules so that they could be presented on a 100-point scale, where 0 meant the worst quality of life while 100 meant the best. The compared group $(n=32)$ consisted of patients with non-resectable pancreatic tumours (grade 3 or 4 ) who were in no shape for thoracovideoscopy due to poor general condition, or co-existing diseases such as chronic obturative pulmonary disease or asthma. The scales and forms were analysed. Seventy-five patients (62\%) reported for control visits. The remaining group either did not come or families refused information about the deceased. The statistical analysis was carried out with SPSS (for Windows) by 
Student's $t$-test. The data are presented as the average \pm standard deviation. Values of $p<0.05$ were accepted as statistically significant.

\section{Results}

In the research material the mean age was comparable in both groups and was 63.2 years old (44 to 86 years old). The series involved $56.6 \%$ women and $43.4 \%$ men. The differences between the control and trial group were statistically non-significant. Before the procedure pain intensity level according to VAS was 5.66 (3.9-7.2; SD 1.24) in the trial group and 5.46 (4.1-7.1; SD 1.15) in the control group (Table I).

The quality of life average assessment in both groups did not differ statistically $(p=1.07)$ and was 46.3 (32-66; SD 0.92) in patients before the operation and in the control group 50.3 (41-63; SD 0.75).

On the $7^{\text {th }}$ postoperative day the average pain intensity was 2.33 (1.2-3.9; SD 0.78) and 4.57 (3.6-5.5; SD 0.69) respectively. One week after the procedure the quality of patients' life was estimated at 64.1 (39-83; SD 1.38), in the control group (after intravenous treatment) at 52.2 (42-65; SD 0.71). The differences are significant $(p<0.05)$ (Table II). Thirty days after the procedure 12 patients did not take any painkillers (13.5\%), and in the others a considerable decrease of the taken medicaments was observed. On average, the pain intensity was estimated at 1.78 (0.6-3.6; SD 0.68), which differed considerably from the estimated pain intensity before and one week after the procedure (Table III). The quality of life, on the other hand, improved considerably in relation to the state prior to the procedure, but increased insignificantly in relation to the state on the $7^{\text {th }}$ postoperative day to 70.9 (52-88; SD 1.14). The differences in the quality of life with analgesic treatment are shown in Figure 1. The mean time of the procedure was $32 \pm 18 \mathrm{~min}$. In 2 patients (1.8\%) perioperative complications in the form of pneumothorax were observed. Suction drainage was used. No other early postoperative (up to 30 days following the procedure)

Table I. Pain intensity according to VAS before the procedure and 7 and 30 days after the procedure in the trial group and on the $1^{\text {st }}, 7^{\text {th }}$ and $30^{\text {th }}$ day of pharmacological treatment of the control group

\begin{tabular}{|lccc|}
\hline VAS & Trial group $(n=89)$ & Control group $(n=32)$ & Values of $p, t$ \\
\hline Before surgery/1 day & $5.66(3.9-7.2 ;$ SD 1.24) & $5.46(4.1-7.1 ;$ SD 1.15) & $t=0.37$, ns \\
\hline After 7 days & $2.33(1.2-3.9 ;$ SD 0.78) & $4.57(3.6-5.5 ;$ SD 0.69) & $t=6.94, p<0.0001$ \\
\hline After 30 days & $1.78(0.6-3.6$; SD 0.68) & $5.96(4.4-7.8 ;$ SD 1.65) & $t=14.37, p<0.001$ \\
\hline
\end{tabular}

Table II. Quality of life based on SF-36 questionnaire before the procedure and 7 and 30 days after the procedure in the trial group and on the $1^{\text {st }}, 7^{\text {th }}$ and $30^{\text {th }}$ day of pharmacological treatment of the control group

\begin{tabular}{|llll|}
\hline SF-36 & Trial group $(n=89)$ & Control group $(n=32)$ & Values of $p, t$ \\
\hline Before surgery/1 day & $46.3(32-66 ;$ SD 0.92) & $50.3(41-63 ;$ SD 0.75) & $t=1.07$, ns \\
\hline After 7 days & $64.1(39-83 ;$ SD 1.38) & $52.2(42-65 ;$ SD 0.71) & $t=2.47, p<0.05$ \\
\hline After 30 days & $70.9(52-88 ;$ SD 1.14) & $46.3(37-58 ;$ SD 0.88) & $t=7.85, p<0.001$ \\
\hline
\end{tabular}

Table III. Statistical significance of cancer pain intensity differences in patients before the procedure and 7 and 30 days after the procedure in the trial group and on the $1^{\text {st }}, 7^{\text {th }}$ and $30^{\text {th }}$ day of pharmacological treatment of the control group

\begin{tabular}{|lccc|}
\hline VAS & Before surgery & After 7 days & After 30 days \\
\hline Before surgery/1 day & $5.66(3.9-7.2 ;$ SD 1.24) & $t=10.71, p<0.0001$ & $t=14.21, p<0.001$ \\
\hline After 7 days & $t=10.71, p<0.0001$ & $2.33(1.2-3.9 ;$ SD 0.78) & $t=1.51, \mathrm{~ns}$ \\
\hline After 30 days & $t=14.21, p<0.001$ & $t=1.51, \mathrm{~ns}$ & $1.78(0.6-3.6$; SD 0.68) \\
\hline
\end{tabular}


Table IV. Statistical significance of the quality of life differences in patients before the procedure and 7 and 30 days after the procedure in the trial group and on $1^{\text {st }}, 7^{\text {th }}$ and $30^{\text {th }}$ day of pharmacological treatment of the control group

\begin{tabular}{|lccc|}
\hline SF-36 & Before surgery & After 7 days & After 30 days \\
\hline Before surgery/1 day & $46.3(32-66 ;$ SD 0.92) & $t=2.66, p<0.05$ & $t=8.26, p<0.001$ \\
\hline After 7 days & $t=2.66, p<0.05$ & $64.1(39-83 ;$ SD 1.38) & $t=1.21$, ns \\
\hline After 30 days & $t=8.26, p<0.001$ & $t=1.21, \mathrm{~ns}$ & 70.9 (52-88; SD 1.14) \\
\hline
\end{tabular}

complications were detected. The mean hospitalization time was 2.2 (1-5; SD 0.82) days in both groups. In all patients operated on, the excision of the nerve tissue was confirmed by histopathological examination.

\section{Discussion}

The idea of quality of life $(\mathrm{QL})$ has been known only recently, since the 1970s. The medical, dynamic development of research concerning QL is observed nowadays. The majority of studies concern chronic and incurable diseases such as carcinoma. Until now, it has been very difficult to define quality of life and unequivocally define issues which should be included in the definition. It remains closely related to the broadly understood term of "health". The World Health Organisation defines it as "a state of complete physical, mental and social well-being and not merely the absence of disease or infirmity" [11]. In 1995 WHO suggested that quality of life should be understood as an "individual's perception of his/her own position in life in the context of the culture and value systems in which he/she lives, and in relation to his/her goals, expectations, standards and concerns" [12]. The results indicate that the assessment made by a patient often differs from the one made by a doctor $[13,14]$. It is connected with the attitude of a doctor towards threats resulting from the patient's clinical condition, while patients concentrate on their subjective impressions. Only the combination of both assessments allows for an appropriate approach towards a patient.

The assessment of pancreatic carcinoma patients' quality of life in the very advanced stage of the disease was the goal of our studies. As mentioned before, in the patients with non-resectable tumour or terminal patients pain treatment presented the most crucial therapeutic problem. A number of therapeutic methods are known nowadays. Videotho-

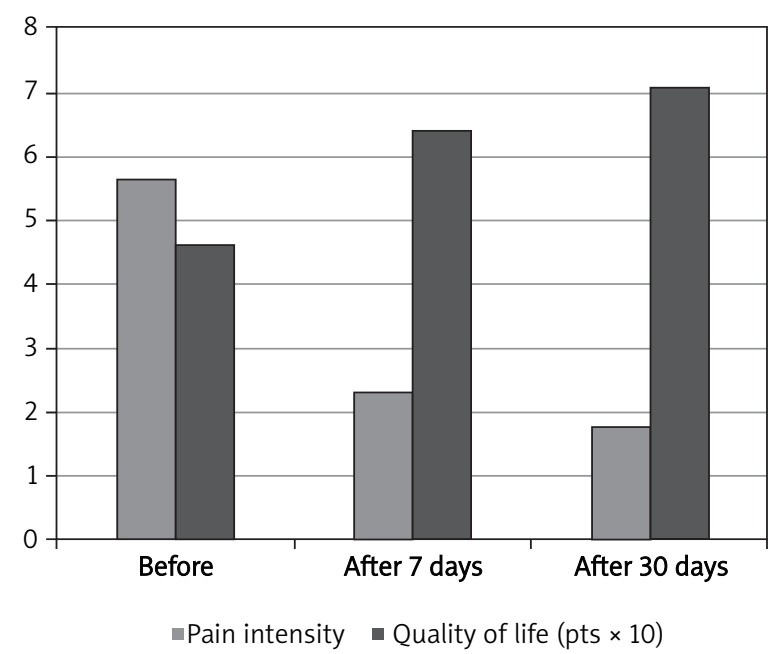

Figure 1. Comparison of changes in the quality of life and cancer pain intensity in patients before the procedure and 7 and 30 days after videothoracoscopic splanchnicectomy

racoscopic splanchnicectomy appears to be the method of choice as it causes exclusion of nerve impulsation in the autonomic nerve system depending on the removed section. The excision of coeliac plexus nerve fragments permits the exclusion of pain impulses from the epigastrium [15]. It is an excellent and acknowledged way of analgesic treatment. Some authors perform concurrent bilateral splanchnicectomy [16-19]. Others think it should be a two-stage procedure and the choice of the first side depends on the location of the major ailment $[20,21]$. There are also cases of the procedure described when the patient is placed face down [19]. In our clinic we do not perform concurrent bilateral splanchnicectomy as we believe every extension of the procedure increases the possibility of complications. The choice of the side operated on was based on the clinical picture. The patients selected for the procedure had obtained unsatisfactory results with pharmacological 
treatment at pain or palliative care clinics. According to world reports in patients having undergone effective splanchnicectomy a considerable improvement was observed [22-26].

Our results are similar and indicate improvement of the quality of life and pain intensity decrease, including discontinuation of painkillers in $13 \%$ of cases. As early as 7 days after the procedure we observed a considerable decrease of pain intensity and a consequent quality of life improvement. Thirty days after the procedure we observed the next improvement of the quality of life with a concomitant decrease of the pain intensity, but these changes were statistically non-significant. In the literature, there are cases described in which after a few years of observation in patients with similar videothoracoscopic procedures such as thoracic or lumbar sympathectomy denervation positive effects and quality of life typically decreased as time went by. The above-mentioned situation can be explained by denervation supersensitivity. It occurs as the result of noradrenalin allergy after postganglionic denervation with excessive increase of sympathetic nervous system tension. Misplaced incision of the sympathetic trunk and the removal of the nerves too lengthy section are the most frequent reasons for such supersensitivity [4, 27-29].

However, in the case of splanchnicectomy performed in carcinoma patients the observation period is relatively short and in the case of grade 3 or 4 tumours does not exceed 2 years [30]. Busher and his team observed that $50 \%$ of chronic pancreatitis patients with splanchnicectomy performed experienced pain again within 12 to 60 months [23]. At the same time Vosschulte and his team observing patients (median observation time: 7 years) with chronic pancreatitis found that in 11 out of 13 patients painful sensations did not return [31].

Similarly good results were obtained by authors of works concerning splanchnicectomy in patients with chronic pancreatic cancer [24, 32]. Literature discrepancies connected with analgesic long duration of positive effect probably arise due to different observation periods of carcinoma and pancreatitis patients. On the other hand, they may also result from changeable anatomy of the visceral nerve and possibly from surgical difficulties with complete disconnection of nerve conduction [5, 20]. The thoracotomy approach (1990) presented a considerable risk for patients with advanced carcinoma disease or oppressive pancreatitis pain and the magnitude of the trauma exceeded the therapeutic effect of postoperative autonomic nervous system excision. Chemical blockades using phenol or alcohol introduced to limit invasiveness did not measure up to expectations due to the lesser efficiency and necessity of repetition [21]. Videothoracoscopy eliminates the above-mentioned inconveniences as a mini-invasive technique allowing for effective and safe excision of visceral nerves and trunks [33, 34]. Of course, this type of procedure is not entirely fault-free. Sometimes bleeding requiring conversion to thoracotomy takes place. After the procedure pneumothorax, pulmonary leakage, Horner's syndrome, emphysema, pleural haemorrhage, or intercostal pain resulting from intercostal nerve contusion at the port site may appear [35, 36].

There were 2 patients (1.8\%) with pneumothorax in our series. Short-term, secondary daily drainage of the pleural cavity expands the lung completely and allows further complications to be avoided. Until 2007 we used drainage of the pleural cavity as a standard. Now we perform it only in certain cases. Muscle or intercostal contusion is especially strenuous for patients [24]. In order to avoid them it is possible not to place thoracic ports [37] and either introduce the instruments directly into the pleural cavity through the chest incision or the pleuroscope can be used for the procedure.

\section{Conclusions}

1. Videothoracoscopic splanchnicectomy is a safe method of cancer pain treatment in patients with advanced pancreatic carcinoma.

2. Videothoracoscopic excision of visceral nerve thoracic section contributes to a statistically significant decrease of cancer pain intensity and considerably improves quality of patients' lives.

\section{References}

1. Puchalski Z, Wasielica M. Przewlekłe zapalenie trzustki. Podstawy leczenia chirurgicznego. Chirurgia po Dyplomie 2007; 2: 17-26.

2. Śmigielski J, Hołyński J, Kococik M, et al. Zabiegi paliatywne w raku pęcherzyka i/lub dróg żółciowych - doświadczenia 5 ośrodków. Pol Merk Lek 2009, XXVI: 416-9.

3. Gossot D, Galetta D, Pascal A, et al. Long-term result of endoscopic thoracic sympathectomy for upper limb hyperhidrosis. Ann Thorac Surg 2003; 75: 1075-9. 
4. Krasna MJ, Jiao X, Sonett J, et al. Thoracoscopic sympathectomy. Surg Laparosc Endosc Percutan Tech 2000; 10: 314-8.

5. Pietrabissa A, Vistoli F, Carobbi A, et al. Thoracoscopic splanchnicectomy for pain relief in unresectable pancreatic cancer. Arch Surg 2000; 135: 332-5.

6. Mallet-Guy P. La splanchnicectomie guache dans le traitement des pancreatities chroniques. Presse Med 1943; 51: 145-6.

7. Stone HH, Chauvin EJ. Pancreatic denervation for pain relief in chronic alcohol associated pancreatitis. Br I Surg 1990; 77: 303-5.

8. Sylwanowicz W, Narkiewicz O. Układ nerwowy autonomiczny. In: Anatomia człowieka. Łasiński W (ed.). PZWL, Warszawa 1989; 280.

9. Dobrogowski J, Sedlak K. Ocena kliniczna chorego z bólem przewlekłym. Ból i jego leczenie. Warszawa, Biuro Gamma 2004.

10. Busiakiewicz A, Rość D. Jakość życia pacjentów z chorobą nowotworową - wybrane techniki badawcze. Annales Academiae Bydgostiensis 2004; 2: 79-81.

11. World Health Organization: The constitution of the World Health Organization. WHO Chron 1947; 1: 29.

12. WHOQOL Group: The World Health Organization quality of life assessment (WHOQOL): position paper from the World Health Organization. Soc Sci Med 1995; 41: 1403-9.

13. Janse AJ, Gemke RJ, Uiterwaal CS, et al. Quality of life: patients and doctors don't always agree: a meta-analysis. J Clin Epidemiol 2004; 57: 653-61.

14. Slevin ML, Plant H, Lynch D, et al. Who should measure quality of life, the doctor or the patient? Br J Cancer 1988; 57: 109-12.

15. Torda TA, Hann P, Mills G, et al. Comparison of extradural fentanyl, bupivacaine and two fentanyl-bupivacaine mixtures of pain relief after abdominal surgery. Br J Anaesth 1995; 74: 35-40.

16. Inderbitzin D, Schmid RA, Schöb O, et al. Surgical pain therapy in inoperable metastatic epigastric tumor by bilateral thoracoscopic splanchnicectomy. Schweiz Med Wochenschr 1998; 128: 1408-13.

17. Rossi M, Zaninotto G, Finco C, et al. Thoracoscopic bilateral splanchnicotomy for pain control in unresectable pancreatic cancer. Chir Ital 1995; 47: 55-7.

18. Tarnowski W, Malec-Milewska M, Bielecki K, et al. Obustronna torakoskopowa splanchnicektomia w leczeniu bólu u chorych z przewlekłym zapaleniem trzustki - roczna ocena prospektywna. Gastroenterol Pol 2004; 11: 449-52.

19. Tomaszewski S, Szyca R, Jasiński A, Leksowski K. Bilateral posterior thoracoscopic splanchnicectomy in a face-down position in the management of chronic pancreatic pain. Pol Merk Lek 2007; 131: 399-401.

20. Le Pimpec Barthes F, Chapuis O, Riquet M, et al. Thoracoscopic splanchnicectomy for control of intractable pain in pancreatic cancer. Ann Thorac Surg 1998; 65: 810-3.

21. Leksowski K. Thoracoscopic splanchnicectomy for control of intractable pain due to advanced pancreatic cancer. Surg Endosc 2001; 15: 129-31.

22. Takahashi T, Kakita A, Izumika H, et al. Thoracoscopic splanchnicectomy for the relief of intractable abdominal pain. Surg Endosc 1996; 10: 65-8.

23. Buscher HC, Jansen JB, van Dongen R, et al. Long-term results of bilateral thoracoscopic splanchnicectomy in patients with chronic pancreatitis. Br J Surg 2002; 89: 158-62.
24. Saenz A, Kuriansky J, Salvador L, et al. Thoracoscopic splanchnicectomy for pain control in patients with unresectable carcinoma of the pancreas. Surg Endosc 2000; 14: 717-20.

25. Johnson CD, Berry DP, Harris S, et al. An open randomized comparison of clinical effectiveness of protocol-driven opioid analgesia, celiac plexus block or thoracoscopic splanchnicectomy for pain management in patients with pancreatic and other abdominal malignancies. Pancreatology 2009; 9: 755-63.

26. Prasad A, Choudhry P, Kaul S, et al. Thoracoscopic splanchnicectomy as a palliative procedure for pain relief in carcinoma pancreas. J Minim Access Surg 2009; 5: 37-9.

27. Obara A, Dziekiewicz M, Koselak M, et al. Sympatykotomia w materiale własnym. Wideochirurgia 2002; 7: 60-2.

28. Bućko W, Winckiewicz M, Goran M, et al. 10 lat doświadczeń w wykonywaniu torakoskopowej sympatektomii piersiowej wskazania, powikłania, wyniki. Wideochirurgia 2005; 10: 32-4.

29. Kordiak J, Brocki M, Jabłoński S, et al. Zastosowanie wideotorakoskopii w leczeniu schorzeń zależnych od autonomicznego układu nerwowego. Videosurgery and miniinvasive techniques 2006; 1: 1-5.

30. Lampe P, Kuśnierz K. Uwagi dotyczące wybranych problemów chirurgii trzustki. Pol Przegl Chir 2008; 80: 527-32.

31. Vosschulte K, Scheld H. Resection procedure or splanchnicectomy in chronic pancreatitis. Indications and comparative results. Munch Med Wochenschr 1977; 119: 1325-8.

32. Chauhan S, Forsmark CE. Pain management in chronic pancreatitis: a treatment algorithm. Best Pract Res Clin Gastroenterol 2010; 24: 323-35.

33. Stefaniak T, Reszetow J, Żemojtel $九$, et al. Videothoracoscopic simultaneous bilateral, posterior splanchnicectomy - initial report. Pol Przegl Chir 2007; 79: 72-8.

34. Leksowski K, Tomaszewski S, Sokala P, et al. Wpływ torakoskopowej splanchnicektomii na natężenie bólu i codzienne życie u chorych z przewlekłym bólem trzustkowym. Gastroenterol Pol 2005; 12: 305-9.

35. Plas EG, Fugger R, Herbst F, et al. Complications of endoscopic thoracic sympathectomy. Surgery 1995; 118: 493-5.

36. Caraceni A, Portenoy RK. Pain management in patients with pancreatic carcinoma. Cancer 1996; 35: 639-53.

37. Leksowski K. Splanchnicektomia torakoskopowa przez jeden otwór. Pol Przegl Chir 2002; 74: 268-9. 